\title{
PEMBINAAN NARAPIDANA NARKOTIKA DAN OBAT OBATAN BERBAHAYA (NARKOBA) DALAM PERSPEKTIF KEHIDUPAN RELIGIUSITAS
}

\author{
Teguh Suratman \\ Fakultas Hukum Universitas Merdeka Malang \\ Jl. Terusan Raya Dieng No. 62-64 Malang \\ teguh.suratman@unmer.ac.id
}

\begin{abstract}
Research on guidance convicts narcotics and drugs dangerous (drug) in perspective life religiousness, carried out with the result that prisoners in the juridical called as the people of under the jurisdiction of drugs since the beginning of caught of law enforcement officers and, caught, for suspected of committing evil drugs, behave evil, against the law, and do their deeds contrary to norms prevailing.Residents under the jurisdiction of drug dealers in a correctional institution the average having intelegensi high, often deeds that is not good escaped monitoring officers although in was captured. In this case, correctional institution as institutions the final sequence in the process of law enforcement and treatment of the illegal drug dealers, to dig, changed his mind evil become religious behavior in his life. Attitude, action, and character the illegal drugs be good and behave religious apparent start submitted for memperosi, the release of parole, and accepted back by the community. For it, viewed the importance of penghayatan toward religion or relied as a basis for behave sehari-hari have owned and used by the illegal drugs, thus religion adopted and course just simbul in yargon referred to islam id card.That it was living in limitation in motion stride, facilities, relations with the other hand, attached to discipline strict rules, especially when is in the cell correctional institution. But, nevertheless with pengayoman restored back.
\end{abstract}

Keywords: Convict Guidance, Narcotics, Religious Life.

\begin{abstract}
ABSTRAK
Penelitian tentang pembinaan narapidana narkotika dan obat obatan berbahaya (narkoba) dalam perspektif kehidupan religiusitas, dilaksanakan dengan hasil bahwa narapidana yang dalam bahasa yuridis disebut sebagai warga binaan narkoba sejak awal tertangkap petugas penegak hukum sedang, kedapatan, patut diduga melakukan kejahatan narkoba, berperilaku jahat, melawan hukum, dan melakukan perbuatan bertentangan dengan norma-norma yang berlaku. Warga binaan pengedar narkoba di lembaga pemasyarakatan rata-rata memiliki intelegensi tinggi, seringkali melakukan perbuatan-perbuatan yang tidak baik lolos dari pantauan petugas walaupun pada akhirnya tertangkap. Dalam hal ini, lembaga pemasyarakatan sebagai institusi urutan terakhir dalam proses penegakan hukum dan perlakuan terhadap warga binaan pengedar narkoba, bertugas menggali, mengubah pikiran jahat menjadi perilaku religius dalam kehidupannya. Sikap, tindakan, dan karakter warga binaan narkoba menjadi baik dan berperilaku religius nampak mulai diajukan untuk memperosi, pelepasan bersyarat, dan diterima kembali oleh masyarakat. Untuk itu, dipandang pentingnya penghayatan terhadap agama atau kepercayaannya sebagai dasar dalam berperilaku sehari-hari belum dimiliki dan digunakan oleh warga binaan narkoba, dengan demikian agama yang dianut dan diyakininya sekedar simbul dalam jargon masyarakat disebut Islam KTP. Bahwa ternyata hidup dalam keterbatasan dalam gerak langkahnya, fasilitas, hubungan dengan pihak lain, terikat pada peraturan disiplin yang ketat, terutama ketika berada dalam sel lembaga pemasyarakatan. Namun, walaupun demikian dengan pengayoman dapat dipulihkan kembali.
\end{abstract}

Kata Kunci: Kehidupan Religiusitas, Narkoba, Pembinaan Narapidana. 
Kejahatan narkoba merupakan fenomena sosial yang terjadi pada setiap tempat dan waktu (Andi Matalata, 1987, 35). Bahkan, disebut sebagai " $a$ universal phenomenon", artinya merupakan fenomena yang berskala universal, dengan model, tipe, modus yang beraneka ragam. Di samping itu, berkaitan dengan berbagai aspek, yaitu sosial, ekonomi, politik, hukum, lembaga pemasyarakatan, budaya, dan sebagainya. Aspek aspek itu, dalam kehidupan sosial saling pengaruh mempengaruhi satu dengan yang lain dalam suatu sistem sosial.

Kejahatan narkoba berkembang sejalan dengan dinamika masyarakat memiliki kharakter unik dan beraneka ragam (Soedjono D, 2004, 60), asusila, merugikan, menimbulkan banyak ketidaktenangan, merusak generasi penerus bangsa, sehingga masyarakat mencelanya dalam bentuk pemberian nestapa dari negara dengan sengaja ditimpakannya (Ruslan Saleh, 1983, 17). Kejahatan narkoba tidak hanya monopoli kaum laki-laki dewasa, akan tetapi dapat dilakukan oleh siapapun, termasuk anak-anak, orang tua, perempuan, waria, pejabat sipil, militer, penegak hukum, pemeluk agama, dan sebagainya. Kejahatannarkoba dalam masyarakat diibaratkan seperti "gunung es", terungkap satu masih tersembunyi (the dark number) sebanyak empat puluh lima (Darmaweda, 1995, 49).

Lembaga pemasyarakatan tidak hanya sekedar tempat untuk menghukum atau menjerakan warga binaan, tetapi berhubungan dengan proses untuk mengubah, memberi bekal mental spiritual, ketrampilan, agar menyadari kesalahan, memperbaiki diri, dan tidak mengulangi kejahatan.

Dengan demikian, kesalehan dan perilaku religius menjadi tujuan dan bekal yang harus dimiliki agar hidup layak dan diterima kembali oleh masyarakat, keluarga, lingkungannya, dan hidup secara wajar seperti sedia kala. Fungsi perilaku dalam kehidupan religius ditanamkan dalam sanubari warga binaan narkoba, oleh karena itu, sistem pemasyarakatan tidak lagi sekadar bertujuan untuk penjeraan/membuat warga binaan jera, tetapi juga merupakan suatu proses pengamatan perilaku warga binaan dalam upaya untuk rehabilitasi, resosialisasi, dan reintegrasi sosial warga binaan ke tengah-tengah masyarakat yang dilandasi oleh kesadaran hidup yang layak selaras dengan normanorma atau kaidah-kaidah sosial.

Lembaga pemasyarakatan sebagai pengayom seyogyanya mampu menepis persepsi negatif keberadaan warga binaan narkoba yang dinilai selepas dari lembaga pemasyarakatan lebih profesional, tempat untuk menimba ilmu kejahatan. Di sisi lain, sejarah menunjukkan bahwa, pada era kepenjaraan maupun era pemasyarakatan perlakuan terhadap warga binaan narkoba menekankan pada penjeraan, cara-cara pembalasan dalam bentuk kekerasan, model seperti ini bertentangan dengan hak asasi manusia, nilai-nilai agama, budaya, dan kehidupan religius. Kondisi seperti ini memperparah penderitaannya.

Kehidupan religius warga binaan, ada tiga syarat, sebagaimana dikatakan oleh Baharudin Lopa, tegaknya hukum dan keadilan, yaitu, Pertama, adanya aturan hukum yang sesuai dengan kaidahkaidah sosial yang hidup dalam masyarakat; Kedua, adanya aparat penegak hukum yang profesional di bidangnya, bermental tangguh atau memiliki integritas moral terpuji serta memiliki jiwa kemanusiaan; Ketiga, adanya kesadaran hukum masyarakat yang memungkinkan dilaksanakan penegakan hukum, (Baharudin Lopa, 1987, 3 - 4), sehingga memiliki jiwa dan semangat "ing ngarsa sung tuladha, ing madya mangun karsa, dan Tut Wuri Handayani".

Pemasyarakatan dengan perangkat aturan hukum yang ada, seharusnya diimbangi dengan penyediaan sarana dan prasarana yang memadai untuk mendukung pelaksanaan pemasyarakatan agar dapat diimplementasikan dalam pemberian bekal kepada warga binaan. Oleh karena itu, falsafah kepenjaraan yang menekankan pada pembalasan tidak sejalan dengan perkembangan 
masyarakat, kemudian diubah dengan falsafah pemasyarakatan yang menekankan pada pengembalian warga binaan kemasyarakat, dengan simbul "pohon beringin pengayoman" telah diterapkan oleh seluruh lembaga pemasyarakatan di Indonesia hingga saat ini.

Di Indonesia, jumlah warga binaan mencapai 144. 953 (seratus empat puluh empat ribu sembilan ratus lima puluh tiga), jumlah ini melebihi kapasitas normal lembaga pemasyarakatan yang hanya mampu menampung 95.000 (sembilan puluh lima ribu) warga binaan, dari jumlah tersebut kurang lebih 45.000 (empat puluh lima ribu) warga binaan narkoba. Kondisi itu menurut Dirjen lembaga pemasyarakatan Kementerian Hukum dan HAM, Sihabudin, perlu pembangunan sarana dan prasarana baru, sejalan dengan semakin tingginya tingkat kejahatan dalam masyarakat.

Lemahnya mental dalam kehidupan religius mencerminkan perlunya pendekatan-pendekatan, pengayoman, kemitraan, mental spiritual dalam penghayatan nilai-nilai keagamaan, dan moral. Kepada seluruh warga binaan narkoba di lembaga pemasyarakatan tanpa terkecuali wajib mengikuti kegiatan-kegiatan yang melibatkan banyak pihak diantaranya para pemuka agama Islam, aktif saatsaat peringatan hari raya keagamaan, mendalami dan menghayati ajaran-ajaran agama, sholat wajib berjamaah, mengaji, puasa, dan sebagainya.

Kehidupan religius dibentuk berlandaskan pada nilai-nilai agama dan keyakinan yang berhubungan dengan dunia dan akhirat, sehingga dalam berperilaku menggunakan ukuran normanorma atau kaidah-kaidah sosial, dan nilai-nilai kearifan lokal. Kehidupan religius tidak memisah misahkan antara yang duniawi dengan yang ukrowi, antara yang seharusnya ada dan tidak ada, antara saya dengan anda, antara suka dengan tidak suka (Krisnamurti, 1978). Kehidupan warga binaan narkoba yang diliputi konflik dalam batin berakibat melakukan kejahatan, dengan memahami konflik internal itu, termasuk latar belakang kehi- dupannya pada akhirnya, petugas lembaga pemasyarakatan diharapkan mampu mengendalikan dari perbuatan jahat.

Warga binaan narkoba dengan menyandang predikat negatif harus dilakukan pendekatan secara benar dan tepat. Hal itu dimaksudkan agar kemampuan untuk mengendalikan kesadaran dan kepekaan diri baik lahiriah maupun batiniah, sehingga terjadi keseimbangan dalam batin, mampu merenungkan kehidupan masa lampau yang kelam, mengedepankan nilai-nilai religius, insyaf, mampu menghadapi masa depan lebih baik.

Berdasarkan hal di atas, penelitian ini dilakukan untuk memperoleh gambaran bagaimana penanganan narapidana atau warga binaan yang tersangkut kasus Narkoba. Penekanannya adalah pembinaan kehidupan keagamaan atau religiusitas para warga binaan dimaksud.

\section{Metode Penelitian}

Penelitian ini merupakan penelitian normatif. Bahwa kemudian ada bahan hukum berupa data empiris itu adalah sebagai legitimasi dari argumentasi yang dibangun di dalam penelitian hukum normatif. Norma yang dibangun didasarkan pada teori sosial yang relevan dengan permasalahan narapidana narkoba yang diarahkan berdasarkan pendekatan religiusitas.

Legitimsi hukum normatif dimaksud, mengambil lokasi di lembaga pemasyarakatan Lowok Waru Malang. Untuk mencapai tujuan itu digunakan pendekatan grounded, pemilihan pendekatan ini dinilai relevan karena mendasarkan pada data-data lapangan yang bersifat empiris melalui observasi/pengamatan.

Jenis penelitian ini adalah penelitian kualitatif menggunakan pendekatan deskriptif analitik dan fenomenologi. Penelitian yang bersifat kualitatif, dengan dasar penelitian hukum normatif sebagaimana dimaksud: 
1) Bahan hukum primer dalam penelitian ini merupakan bahan hokum yang dikaji berdasarkan prinsip hukum normatif yang meliputi sinkronisasi dari berbagai peraturan perundangan yang relevan.

2) Data sekunder dalam penelitian ini merupakan dokumen-dokumen resmi, buku-buku, majalahmajalah, surat kabar, dan arsip data-data warga binaan dari lembaga pemasyarakatan.

\section{Konsep Kehidupan dan Kehidupan Religius}

Kehidupan secara konkret tercermin dalam sebuah perilaku. Perilaku manusia yang dapat diamati dengan pancaindera dan bias diukur berdasarkan ukuran kuantitatif. Dalam kaitan ini, perilaku adalah kegiatan atau aktifitas baik yang dapat diamati langsung maupun yang tidak dapat diamati langsung oleh pihak luar (Notoatmodjo, 2003, 114). Sedangkan menurut Skiner (1938), respon atau reaksi seseorang terhadap stimulus (rangsangan dari luar). Oleh karena itu, perilaku terjadi melalui proses adanya stimulus terhadap organisme, kemudian organisme memberikan respon. Sekumpulan perilaku yang dimiliki manusia dan dipengaruhi oleh adat, sikap, emosi, nilai, etika, kekuasaan, persuasi, dan atau genetika (Albarracin, Dolores et. al 2005, 74-78).

Domain perilaku, walaupun bentuk stimulusnya sama, namun respon yang diberikan warga binaan berbeda-beda. Faktor yang membedakan disebut dengan diterminan perilaku, yang dibedakan menjadi (1). Faktor internal warga binaan, karakteristik yang bersangkutan yang bersifat bawaan (given), misalnya, tingkat kecerdasan, emosional, jenis kelamin, dan sebagainya, (2). Faktor eksternal warga binaan, yaitu lingkungan, misalnya, fisik, ekonomi, politik, agama, dan sebagainya. Ditegaskan pula oleh Notoatmodjo, faktor lingkungan menjadi faktor dominan yang mewarnai perilaku warga binaan (Notoatmodjo, 2007, 139).
Religius adalah bersifat keagamaan atau yang berkenaan dengan kepercayaan terhadap agama. Sedangkan religi berhubungan dengan akidah, kepercayaan, dan agama.

Perilaku religius, perilaku yang dilandasi oleh nilai-nilai agama, kepercayaan, begitu pula sejalan dengan nilai-nilai budaya, dan nilai-nilai kearifan lokal. Hal itu harus dimiliki oleh warga binaan sebagai pedoman dalam kehidupannya. Nilai-nilai itu diupayakan untuk ditanamkan pada warga binaan selama proses pemasyarakatan.

Warga binaan narkoba mengadopsi perilaku baru dalam proses yang urut, yaitu (1) kesadaran (awareness), (2) ketertarikan (interest), (3) menimbangnimbang baik buruknya stimulus bagi dirinya (evaluation), (4) mencoba perilaku baru (trial), (5) berperilaku baru sesuai dengan pengetahuan, kesadaran, dan sikapnya terhadap stimulus (adaptation). Apabila penerimaan perilaku baru atau adopsi perilaku itu melalui proses pengetahuan, kesadaran, dan sikap positif, maka perilaku itu pada akhirnya menjadi kebiasaan atau bersifat langgeng (long lasting) (Notoatmodjo, 2003, 122).

\section{Konsep Warga binaan}

Dalam Black's Law Dictionery, pengertian "prisoner, one who is deprived of his liberty. One who is against his will kept in confinement or custudy in a prison, penitentiary, or jail as a result of conviction of crime"(Henry Campbell Black, 1979, 1075).

Istilah warga binaan digunakan pada era kepenjaraan, mengalami perubahan mengikuti dinamika masyarakat dengan istilah warga binaan. Perubahan istilah ini sejalan dengan falsafah yang menjadi landasan perlakuan terhadap warga binaan di dalam lembaga pemasyarakatan yaitu falsafah pemasyarakatan.

Perlidungan hak asasi warga binaan narkoba sesungguhnya merupakan bagian dari perlindungan hak asasi manusia. Di dalam perkembangan konsep hukum, perlindungan hak-hak warga 
binaan telah mengalami perubahan pesat. Hal ini sejalan dengan perkembangan hukum di dunia maupun perkembangan hukum di Indonesia. Sejalan dengan ini, betapapun jahatnya warga binaan narkoba tidak boleh diperlakukan sebagai obyek yang bisa disakiti jiwa dan raganya, kondisi demikian merupakan tantangan besar bagi penegak hukum dalam menegakkan hukum serta memperlakukan warga binaan.

Pasal 1 ke 32 Kitab Undang-Undang Hukum Acara Pidana Undang-Undang Nomor 8 Tahun 1981 Tentang Hukum Acara Pidana, pengertian terpidana adalah seorang yang dihukum berdasarkan putusan pengadilan yang telah memperoleh kekuatan hukum tetap. Sejak saat itulah terjadi pergeseran status dari terdakwa menjadi terhukum, dan menjadi warga binaan, untuk terhukum hilang kemerdekaan dimasukkan ke dalam lembaga pemasyarakatan.

Menjalankan proses re-integrasi, hak-hak warga binaan narkoba yaitu cuti mengunjungi keluarga, asimilasi, pembebasan bersyarat, cuti menjelang bebas, remisi, dan sebagainya. Proses ini diberikan apabila warga binaan berperilaku baik pada tiap-tiap tahap pembinaan, telah menunjukkan perilaku baik. Hal ini berdasarkan hasil pengamatan dan evaluasi yang dilakukan oleh petugas lembaga pemasyarakatan dan pengawasan dari hakim pengawas dan pengamat.

Warga binaan berhak untuk tidak diperlakukan sebagai pesakitan dan diasingkan dari lingkungan masyarakat, memperoleh pendidikan yang layak, menjalankan ibadah, mendapat perawatan jasmani maupun rohani, pendidikan dan pengajaran, pelayanan kesehatan, makanan yang layak, menyampaikan keluhan, memperoleh fasilitas untuk informasi, mendapatkan upah atau premi atas pekerjaan yang dilakukan, menerima kunjungan keluarga dan penasehat hukum, remisi, assimilasi dan mengunjungi keluarga, pembebasan bersyarat, cuti menjelang bebas, dan sebagainya.
Secara ideal, warga binaan diposisikan sebagai subyek yang benar-benar dibina secara baik, namun dalam kenyataan banyak perlakuan terhadap warga binaan narkoba sebagai obyek yang diperlukukan kasar, keras, tidak manusiawi, bahkan di luar batas-batas perikemanusiaan.

\section{Lembaga Pemasyarakatan}

Pemasyarakatan sebagai sistem perlakuan terhadap warga binaan pada saat ini, dilatarbelakangi oleh fenomena yang terjadi di dalam masyarakat. Fenomena tersebut terkait dengan lemahnya penghargaan terhadap hak-hak asasi warga binaan.

Penghargaan itu diantaranya menempatkan warga binaan sebagai subyek, bukan obyek yang diperlakukan secara kasar atau semena-mena, sehingga menimbulkan penderitaan lahir dan batin. Sesungguhnya warga binaan adalah anggota masyarakat yang berperilaku jahat, melanggar norma-norma, dicela oleh masyarakat, walaupun demikian tetap dihargai hak-haknya, sehingga dalam memperlakukan warga binaan tunduk pada aturan-aturan, kaidah-kaidah/norma-norma yang berlaku pada saat ini.

Fenomena yang berkembang di masyarakat, pemasyarakatan sebagai tempat menimba ilmu kejahatan, hal ini menimbulkan efek negatif terhadap lembaga pemasyarakatan, dipertegas lagi dengan kejadian-kejadian, provokator kerusuhan, mengendalikan bisnis narkoba, menyuap petugas untuk memperoleh fasilitas yang mewah seperti fasilitas di hotel berbintang, berkelai, melakukan homoseksual, melarikan diri dari lembaga pemasyarakatan, menjadi residivis, kejiwaannya tertekan, dan sebagainya.

Pemasyarakatan dengan falsafah pengayoman, berfungsi untuk mengayomi warga binaan/ warga binaan agar menjadi manusia yang berguna dan bermanfaat untuk kepentingan pembangunan 
masyarakat. Hal ini dilakukan dengan cara menerapkan program pembinaan warga binaan dengan tahapan, etmisi orientasi, setengah dari masa pidananya, dua pertiga dari masa pidananya, dan pelepasan bersyarat (Romli Atmasasmita, 1988, 124). Penerapan tahap-tahap pembinaan harus memperhatikan berbagai aspek yang berhubungan dengan kondisi warga binaan.

Saat ini, estimasi jumlah penduduk Indonesia kurang lebih 259.000.000 (dua ratus lima puluh sembilan juta), bila dibandingkan dengan jumlah warga binaan kurang lebih 149.285 (seratus empat puluh sebilan ribu duaratus delapan puluh lima ribu). Jumlah ini menunjukkan angka yang besar, kecenderungan kejahatan meningkat seiring dengan perkembangan masyarakat. Kondisi seperti ini merupakan persoalan dalam masyarakat yang harus diatasi secara simultan dengan memperhatikan berbagai elemen.

Kehidupan warga binaan di dalam lembaga pemasyarakatan sebagai individu, serta di luar lembaga sebagai kepala keluarga. Di samping itu, pada warga binaan melekat stigma atau cap sebagai penjahat dan tindakan kekerasan sebagai identitas yang tidak terpisahkan dengan dirinya.

Program pembinaan warga binaan dengan sistem pemasyarakatan, dilaksanakan dengan melalui empat tahap pembinaan, pertama, masa etmisi dan orientasi, pada masa ini warga binaan dimintai berbagai macam informasi yang berhubungan dengan berbagai kepentingan pembinaan; kedua, mencapai masa sepertiga dari masa pidananya; ketiga, mencapai dua pertiga masa pidananya; keempat, memperoleh pelepasan bersyarat.

Menangani mekanisme kinereja di LP dilakukan oleh petugas lembaga pemasyarakatan. Dalam kaitan ini, petugas bui/sipir dalam sistem kepenjaraan mempunyai tugas menangani warga binaan di Penjara dan mengamati perkembangan perilaku warga binaan. Kemudian pada Zaman Penjajahan Jepang, hal-hal yang berhubungan de- ngan kepenjaraan tidak banyak mengalami perubahan, termasuk istilah sipir masih tetap digunakan. Perlakuan kejam dan tidak manusiawi nampakpada saat itu, wajib melakukan kerja paksa, sehingga banyak yang meninggal dunia. Dalam catatan sejarah merupakan lembaran hitam dalam kepenjaraan abad ke 19.

Sistem pemasyarakatan, peranan petugas pemasyarakatansangat penting untuk mengubah perilaku warga binaan. Di samping itu, sebagai pelaksana visi, misi program pemasyarakatan terhadap warga binaan, keberhasilan pembinaan bergantung pada peran petugas lembaga pemasyarakatan, oleh karena itu keberhasilan untuk menbina, mengubah perilaku warga binaan berada pada petugas sebagai ujung tombak dalam pembinaan dalam upaya mengubah perilaku warga binaan.

Mencermati peran petugas lembaga pemasyarakatan yang sangat penting/strategis, sejalan dengan perkembangan modus kejahatan yang terjadi di masyarakat, kualitas dan kuantitasnya selalu ditingkatkan, di samping harus meningkatkan sarana dan prasarana pendukung.

\section{Hak dan Kewajiban Narapidana Narkoba}

Kewajiban-kewajiban sebagai dasar pembinaan harus ditaati, dipatuhi, dan diterima sebagai pedoman oleh warga binaan sejak warga binaan menjalani hukumannya dan berstatus warga binaan. Hal ini merupakan bagian dari upaya untuk membina mental spitual untuk setiap pribadi warga binaan itu sendiri. Indikatornya adalah ketaatannya terhadap aturan-aturan yang ada, kewajiban-kewijiban yang harus dipatuhi, dan evaluasi yang dilakukan oleh petugas lembaga pemasyarakatan, dibantu oleh hakim pengawas dan pengamat (hakim wasmat) yang telah ditunjuk oleh ketua pengadilan negeri yang berkompeten.

Di samping itu, warga binaan dibebani kewajiban-kewajiban dalam upaya untuk disiplin, 
patuh dan taat guna untuk mengubah perilakunya yang ditetapkan oleh Lembaga pemasyarakatan. Warga binaan juga mempunyai hak, sebagaimana layaknya manusia yang mempunyai hak asasi atau hak dasar yang melekat sejak lahir. Pada akhirnya, akibat dari suatu kesalahan yang telah diperbuat yaitu melakukan tindak pidana/kejahatan narkoba, maka ia harus rela kehilangan kemerdekaannya atau kebebasannya untuk tetap berada di tengah-tengah masyarakat luas, dan harus masuk/ dikurung dalam lembaga pemasyarakatan, bahkan dimasukkan dalam sel.

Warga binaan yang baru menjalani masa pidananya harus segera beradaptasi dan berinteraksi dengan warga binaan lain yang senior atau telebih dahulu menjadi warga binaan. Di samping itu, juga harus berperilaku baik, tidak melanggar peraturan tata tertib lembaga dan nilai-nilai kearifan lokal lembaga pemasyarakatan.

Kehidupan religius pada dasarnya merupakan kehidupan dasar yang didambakan oleh Bangsa Indonesia, hal ini merupakan cerminan dari nilai-nilai luhur warisan budaya bangsa yang terkristalisasi dalam rumusan sila-sila dalam Pancasila. Perlakuan terhadap warga binaan narkoba juga bertujuan dan berpedoman pada hal yang demikian.

Sikap warga binaan narkoba seyogyanya sejalan dengan idiologi yang dicita-citakan yaitu idiologi Pancasila, sebagai sumber dari segala sumber hukum, pandangan hidup bangsa, pedoman hidup bangsa, dan sebagainya. Oleh karena itu, sikap warga binaan narkoba sejalan dengan falsafah pengayoman, selaras dengan cita-cita luhur bangsa, guna untuk memulihkan kondisinya seperti sedia kala.

Hasil observasi peneliti dari lapangan, ketika berinteraksi di dalam lembaga pemasyarakatan, warga binaan narkoba bersikap mengedepankan nafsu dan emosinya, telah disadarkan bahwa mengedepankan nafsu derajatnya tidak jauh berbeda dengan makluk Allah yang paling rendah yaitu hewan atau binatang. Mereka telah terperok dalam kejahatan, berperilaku buruk dan jahat, yaitu penjahat narkoba, kemudian ditangkap dan diproses hukum, divonis oleh hakim masuk ke dalam lembaga pemasyarakatan, memperoleh predikat sebagai warga binaan narkoba. Lembaga pemasyarakatan sebagai tempat akhir dari penjahat setelah melalui proses hukum, harus mengubah sikap jahat menjadi warga binaan yang tidak jahat atau religius.

Guna untuk membentuk sikap kehidupan religius warga binaan narkoba dalam keseharian dalam lembaga pemasyarakatan, dibangun sarana fasilitas tempat-tempat ibadah, salah satu diantaranya adalah pembangunan Masjid dalam lembaga pemasyarakatan diberi nama Masjid At'Taubah, nama yang tepat untuk tempat berbagai kegiatan keagamaan dan tempat menggembleng warga binaan narkoba.

Bagi warga binaan pengedar narkoba yang beragama Islam, menjalankan kegiatan keagamaan menggunakan sarana masjid dipandu oleh mubalig dan petugas lembaga pemasyarakatan.

Bakti sosial warga binaan dilakukan untuk "berbagi kasih dengan sesama", saling peduli, memahami serta merasakan bahwa mereka hidup bermasyarakat, walaupun mereka terhukum, tidak dekat dengan keluarga, sanak saudara, serta sahabat karip. Kegiatan ini menciptakan solidaritas, kepedulian, sarana rekreasi, dan upaya sosialisasi dengan masyarakat.

Kegiatan bakti sosial menjadi program rutin lembaga pemasyarakatan Lowokwaru Malang. Kegiatan ini dilaksanakan untuk mendukung program lain. Bakti sosial dilakukan untuk warga binaan pengedar narkoba ke luar maupun dari luar masuk ke dalam lembaga pemasyarakatan.

Warga binaan narkoba di lembaga pemasyarakatan Lowokwaru Malang dalam berinteraksi memiliki sikab yang beraneka ragam. Sikap merupakan kecenderungan individu untuk merespon dengan cara yang khusus terhadap stimulus yang 
ada dalam lingkungan sosial (Howard dan Kendler, 1974; dalam Gerungan 2000). Sikap warga binaan, merupakan suatu kecenderungan untuk mendekat atau menghindar, positif atau negatif terhadap berbagai keadaan sosial, apakah itu kelompok, pribadi, situasi, ide, konsep, kepatuhan, kesalehan dalam agama, jujur, dan sebagainya.

Sikap warga binaan, merupakan suatu keadaan internal yang mempengaruhi pilihan tindakan individu terhadap beberapa obyek, pribadi, dan peristiwa (George; 1974).

Di dalam lembaga pemasyarakatan, perilaku warga binaan, dari hasil observasi peneliti dipengaruhi oleh adat istiadat atau asal usul warga binaan, emosi, nilai-nilai yang dianut, etika, strata dalam lingkungan warga binaan, persuasi, genetika, dan sebagainya. Faktor-faktor tersebut mempengaruhi pembentukan sikap dan pribadi warga binaan. Perilaku warga binaan diukur dan diatur dengan norma-norma sosial dan berbagai kontrol sosial atau seringkali disebut dengan nilai-nilai kearifan lokal yang berlaku.

Sikap warga binaan pengedar narkoba pada dasarnya jahat, hal ini terbukti secara hukum melalui proses peradilan yang mempunyai kekuatan hukum tetap. Upaya lembaga pemasyarakatan untuk mengubah perilaku jahat terbukti banyak yang memperoleh remisi atau pengurangan hukuman serta tidak melakukan kejahatan lagi.

Suatu hal penting yang terjadi di lembaga pemasyarakatan Lowokwaru Malang, yaitu nilainilai kearifan lokal, tiap-tiap lembaga pemasyarakatan di Indonesia memiliki kharakter khusus yang beraneka ragam, aspek ini mempunyai peran pendamping peraturan perundang-undangan atau kaidah-kaidah sosial yang menjadi pijakan dalam proses pemasyarakatan.

Di sisi lain, bahwa perlakuan terhadap warga binaan pengedar narkoba, tidak boleh kaku dalam mensikapi ketentuan perundang-undangan atau kaidah-kaidah sosial yang ada agar nilai-nilai pengayoman dirasakan pengaruhnya.
Pada perspektif religiusitas, nilai-nilai Agama dan nilai-nilai kearifan lokal menjadi resource yang memberikan kontribusi besar dalam penyesuaian diri dalam menghadapi stres. Di samping itu, dapat pula dijadikan filter/penyaring pengaruh negatif yang serba cepat dan canggih, agar tidak mempengaruhi dan membelenggu warga binaan dan menambah beban penderitaan warga binaan di lembaga pemasyarakatan.

Keberadaan masjid di lembaga pemasyarakatan sangat penting manfaatnya yaitu untuk mencerdaskan warga binaan, membina mental spiritual, dan aklaknya, guna menjadi warga binaan seutuhnya, menyadari kesalahannya, memperbaiki diri, tidak mengulangi lagi kejahatan, sehingga dapat kembali ke tengah-tengah masyarakat, serta ikut ambil bagian dalam pembangunan, hidup secara wajar sebagai warga negara yang baik dan bertanggung jawab. Begitu juga sarana dan fasilitas ibadah yang lain, seperti Hindu, Budha, Kristen, dan Katolik.

Warga binaan yang mengikuti kegiatan keagamaan dengan tujuan agar tercipta kesalehan pada tiap individu, kesalehan sosial dengan mempertahankan dan menjaga prinsip-prinsip kemanusiaan berupa peningkatan toleransi antar umat manusia, kesadaran yang tinggi, dan bermartabat. Masjid dengan penjara selaras dengan prinsip pemasyarakatan, sehingga adagium "di masjid bagaikan di penjara" berubah menjadi "di penjara bagaikan di masjid".

\section{Perbuatan Warga Binaan Narkoba Dalam Kehidupan Religius}

Bahwa di dalam kehidupan sosial warga binaan narkoba yang sedang menghuni lembaga pemasyarakatan, meyakini bahwa kehidupan di dunia adalah kehidupan yang sifatnya sesaat/ sementara, dari tidak ada menjadi ada, lalu akan meninggalkan alam dunia menuju ke alam fana. Dengan kata lain, rangkaian siklus kehidupan manusia adalah dari alam arwah, alam rahmi, alam 
dunia, kemudian mamasuki alam barzah, dan alam akhirat. Itulah etape perjalanan manusia yang sudah, sedang, dan akan dilalui oleh siklus kehidupan yang harus diketahui dan diyakini oleh warga binaan pengedar narkoba.

Hasil observasi peneliti dari lapangan, disampaikan di Masjid At'Taubah terkait dengan bagian dari materi ceramah kepada warga binaan narkoba, dijelaskan pada setiap etape perjalaman kehidupan warga binaan terdapat suatu proses perjalanan panjang sebelum sampai pada perhitungan akhir, yaitu hari perhitungan (Yaumul Hisab), sebagai bentuk pertanggung jawaban kepada sang pencipta, Allah SWT atas segala bentuk perbuatan yang telah dilakukan. Menyadarkan warga binaan tentang pentingnya mengetahui dan meyakini hal itu menjadi tanggung jawab masing-masing pribadi sebagai hamba Allah SWT.

Predikat sebagai penjahat, kriminal, kotor, sampah masyarakat, biang kriminal dan sebagainya adalah cap atau stigma yang melekat kepada warga binaan narkoba. Citra negatif yang memarjinalkan atau meminggirkan status warga binaan pengedar narkoba memberikan cap atau stigma negatif, dan menjauhkan dari nilai-nilai budaya masyarakat, memiliki cara dan tradisi yang berbeda dengan masyarakat lain dalam menjalankan kegiatan atau aktivitas keseharian.

Di sisi lain, kontruksi sosial merupakan sebuah pandangan bahwa semua nilai, idiologi, dan institusi sosial adalah buatan manusia. Sehubungan dengan itu diperlukan waktu untuk memahami dan menghargai implikasi dari pernyataan itu. Sebagai contoh, di masa lampau warga binaan narkoba adalah penjahat yang diidentikkan sebagai obyek/barang yang dapat diperlakukan secara kasar dan semena-mena agar supaya jera/kapok. Dengan munculnya Sahardjo, mengubah paradigma itu menjadi lebih manusiawi dan lebih humanis, menempatkan warga binaan sebagai subyek.
Kontruksi sosial adalah sebuah pernyataan keyakinan (a claim), sebuah sudut pandang (a viewpoint), bahwa kandungan dari kesadaran, dan cara berhubungan dengan orang lain itu diajarkan oleh kebudayaan dan masyarakat. Tercakup di dalamnya pandangan bahwa semua kualitas metafisik itu riil dan abstrak yang dianggap sebagai suatu kepastian, itu dipelajari dari orang lain di sekitarnya (Ian Rory, 1997).

Pendekatan kontruksi sosial lahir dari beberapa sumber, seperti interaksionisme sosial, antropologi simbolik, pendekatan ini lebih menekankan pada pengaruh budaya dalam memberikan suatu kerangka bagi suatu pengalaman dan pemaknaan kehidupan religius warga binaan pengedar narkoba. Dengan demikian kontruksi sosial secara tegas menyertakan budaya warga binaan sebagai faktor kunci untuk memahami perbuatan/tindakan yang dilakukan, lebih-lebih dalam kehidupan religius.

Pemahaman terhadap individu warga binaan narkoba, pengetahuan dan diri individu terbentuk dalam kondisi sosial dan latar belakang kehidupan yang konkrit, hal itu dihubungkan dengan apa yang disebut sebagai discourse, yakni berupa sejumlah gagasan dan argumen yang langsung berkaitan dengan teknik-teknik kontrol demi eksistensi warga binaan narkoba.

Tanpa memandang darimana eksistensi itu berasal, yang penting diakui oleh warga binaan narkoba yang lain, tetapi eksistensinya yang mendefinisikan pengetahuan, melakukan penilaian apa yang baik dan apa yang buruk, yang boleh dan yang tidak boleh, mengatur perilaku, mendisiplinkan dan mengontrol segala sesuatu, dan bahkan menghukumnya atau memberi sanksi. Artinya warga binaan narkoba sebagai individu juga dibentuk dan diatur oleh petugas lembaga pemasyarakatan. Hal ini dapat menggambarkan bagaimana kontruksi sosial warga binaan narkoba dalam kehidupan religius dapat mempengaruhi perilaku dan orientasi sosial. 
Dunia warga binaan tidak dapat dipisahkan dengan dunia sosial (Berger dan Luckman, 1991, 1). Hasil observasi peneliti dari lapangan, realitas sosial warga binaan narkoba terbentuk secara sosial dari lingkungannya. Realitas kehidupan sehari-hari warga binaan narkoba memiliki dimensi obyektif dan subyektif dalam lingkungan sosial lembaga pemasyarakatan. Warga binaan narkoba merupakan instrumen dalam menciptakan realitas sosial yang obyektif melalui proses eksternalisasi dan proses internalisasi, pada akhirnya melahirkan perbuatan Jahat.

Sebagaimana dikatakan oleh Soetandyo Wignjosoebroto (2001), menyatakan realita sebagai sesuatu yang nampak sebenarnya adalah fakta, namun dalam maknanya yang tidak hanya sebagai sesuatu yang disadari, diketahui, atau bahkan yang dipahami dan diyakini (realized) boleh dan ada di dalam alam pemikiran manusia. Maka realitas tak mesti hanya berhenti pada konsep realita sebagai realita individu, melainkan realita yang menjadi bagian dari kesadaran, pengetahuan, dan/atau keyakinan suatu kelompok sosio-kultural warga binaan narkoba.

\section{Kebiasaan Warga Binaan Narkoba dalam Kehidupan Religius}

Konsep kebisaan atau habit, a disposition or condition of the body or mind acquired by custom or a usual repetition of the same act or fungtion. The custumery conduct, to pursue which one has accuired a tendency, from frequent repetition of the same acts (Henry Campbell Black, 1979, 639). Kebiasaan segala sesuatu yang diulang-ulang, pada akhirnya menjadi sesuatu yang melembaga.

Hasil observasi peneliti dari lapangan, untuk membentuk kebiasaan perilaku religius harus bekerja keras, dilakukan secara berulang ulang untuk menanamkan nilai-nilai agama dan kepercayaan kepada warga binaan, upaya ini dilakukan dengan maksud agar supaya warga binaan mampu merenung dan merepleksikannya terhadap dosadosa yang telah dilakukan terhadap nilai-nilai agama dalam kehidupan sehari-hari, baik di dalam lembaga pemasyarakatan maupun kelak setelah bebas dari lembaga pemasyarakatan.

Antara moral dan etika sesungguhnya tidak sama, moral adalah hal yang berhubungan dengan bagaimana manusia itu hidup, sedangkan etika adalah usaha manusia untuk memakai akal budi dan daya fikirnya untuk memecahkan masalah bagaimana ia harus hidup kalau ia mau menjadi baik (Suseno, 2000, 14-17). Moral dan etika dipupuk dengan kegiatan yang mendorong warga binaan narkoba berperilaku religius. Adapun perbuatan yang mengarah pada kegiatan religius warga binaan narkoba dibiasakan untuk melakukan kegiatan sebagai berikut:

1. Berdoa dan bersyukur kepada Tuhan Yang Maha Esa sebagai sang pencipta

2. Melaksanakan kegiatan keagamaan di Masjid At'Taubah Lowokwaru Malang

3. Merayakan hari raya keagamaan

4. Melaksanakan kegiatan keagamaan yang telah ditentukan sesuai dengan program lembaga pemasyarakatan.

Membangun kebiasaan yang baik dan religius dalam kehidupan sehari-hari dilakukan dengan menanamkan hubungan persaudaraan antara sesama warga binaan narkoba tanpa dipengaruhi oleh suku, ras, agama, dan golongan, misalnya saling memberi ucapan selamat ketika peringatan hari raya Agama Islam, ulang tahun, dan sebagainya. Di samping itu, di lembaga pemasyarakatan Lowokwaru Malang juga ditanamkan rasa sayang terhadap sesama manusia, makluk lain, dan melestarikan lingkungan, misalnya membuang sampah pada tempatnya, memperlakukan binatang dengan baik, memelihara tanaman di sekitar lembaga pemasyarakatan, dan sebagainya.

Hasil observasi peneliti tentang kegiatan di lembaga pemasyarakatan Lowokwaru Malang, 
dibiasakan dilaksanakan kegiatan pesantren kilat, kemah religius, bakti sosial, mendatangkan dai cilik, dan sebagainya. Hal ini dilakukan agar warga binaan tumbuh rasa toleransi yang tinggi, menghargai berbedaan, sehingga terjalin hubungan yang harmonis, tenteram, dan damai, sehingga warga binaan narkoba merasakan betul indahnya kebersamaan dalam keragaman, sehingga merasakan bahwa semua adalah saudara yang perlu dihormati, dihargai, dikasihi, disayangi seperti keluarga sendiri.

Warga binaan yang memiliki nilai-nilai pemahaman keagamaan yang baik, membentuk pribadi mampu bersifat kritis terhadap hal-hal yang ada di sekitarnya. Nilai-nilai agama juga menjadi filter menangkal memori negatif, pengaruh-pengaruh buruk, dan nafsu jahat pada warga binaan. Di lembaga pemasyarakatan Lowokwaru Malang, warga binaan pengedar narkoba yang beragama Islam wajib mengikuti peringatan hari-hari besar Islam yang diselenggarakan di Masjid.

Di Lembaga Pemasyarakatan Lowokwaru Malang, siraman rohani yang disampaikan para mubaliq, wajib diikuti, program tersebut dilaksanakan dengan bimbingan dan arahan yang intensif dengan pengawasan ketat oleh petugas lembaga pemasyarakatan.

Kegiatan-kegiatan ritual keagamaan, penyelenggaraannya menggunakan metode ceramah, tanya jawab, demonstrasi dan praktek langsung. Petugas lembaga pemasyarakatan Lowokwaru Malang bekerjasama dengan berbagai pihak. Setelah program dilaksanakan, untuk mengetahui sejauhmana kegiatan diterima oleh warga binaan, diadakan evaluasi. Evaluasi dilakukan secara lisan, secara praktek, dan hasilnya dapat dilihat dari kebiasan dan perilaku sehari-hari dalam berinteksi dengan sesama warga binaan, dengan petugas lembaga pemasyarakatan.

Hasil observasi yang dilakukan peneliti, untuk menciptakan kehidupan religius di lembaga pemasyarakatan, harus tercipta situasi dan kondisi yang aman, tertib dan tenteram. Hal ini merupakan sarat untuk proses penciptaan kehidupan religius, yang ditandai dengan terjaminnya keamanan, ketertiban, tegaknya hukum, serta terbinanya ketentuan yang mengandung kemampuan dan kekuatan masyarakat warga binaan dalam menangkal, mencegah, dan menanggulangi segala bentuk pelanggaran hukum dan tata tertib, termasuk isuisu terkini yang terjadi di lembaga pemasyarakatan, diantaranya, residivis, konflik horisontal, konflik vertilal, krisis moral, lembaga pemasyarakatan tempat untuk menimba ilmu kejahatan, uang sogok, narkoba, dan sebagainya.

Terciptanya kedamaian, keharmonisan, kenyamanan hidup warga binaan, walaupun gerak langkahnya dibatasi hal ini tidak menjadi beban penderitaan. Hal ini sejalan dengan tujuan pemasyarakatan untuk membentuk warga binaan menjadi anggota masyarakat yang berguna, adil dan sejahtera, ikut dalam berbagai kegiatan/aktivitas di masyarakat baik di perusahaan-perusahaan maupun pembinaan mental di tempat-tempat ibadah.

\section{Faktor yang Melatarbelakangi Perilaku Warga Binaan Narkoba}

Bahwa perilaku adalah kegiatan atau aktifitas, baik yang dapat diamati langsung maupun yang tidak dapat diamati langsung oleh pihak luar (Notoadmojo, 2003, 114). Perilaku warga binaan terjadi ketika berinteraksi dengan yang lain di lembaga pemasyarakatan, terjadi antar individu warga binaan, individu dengan kelompok warga binaan, kelompok dengan kelompok warga binaan.

Interaksi di lembaga pemasyarakatan terjadi antara individu dengan kelompok warga binaan dengan petugas lembaga pemasyarakatan. Interaksi itu terjadi berhubungan dengan kegiatan dalam proses pemasyarakatan untuk menciptakan, membentuk, dan mengembangkan kebiasaan- 
kebiasaan sebagai realisasi dalam upaya untuk mewujudkan visi dan misi lembaga pemasyarakatan.

Faktor-faktor internal adalah faktor dari warga binaan yang mempengaruhi perilaku warga binaan yang nampak dalam interaksi dan kehidupan di lembaga pemasyarakatan.

Adapun hasil observasi peneliti faktorfaktor yang mempengaruhi perlakuan terhadap warga binaan narkoba, dipengaruhi oleh beberapa faktor yang berperan penting dan berpengaruh dalam proses perlakuan terhadap warga binaan narkoba di lembaga pemasyarakatan, antara lain, faktor yang berasal dari warga binaan itu sendiri, faktor pendidikan, faktor agama atau keyakinannya, faktor ketrampilan, dan faktor usia.

Di sisi lain, status sosial, ekonomi, proses hukum mulai dari kepolisian, kejaksaan, dan pengadilan ikut mempengaruhi kondisi kejiwaan warga binaan. Keadaan itu tidak mencerminkan nilai-nilai rasa keadilan pada warga binaan, sehingga berpengaruh terhadap perilaku warga binaan di lembaga pemasyarakatan.

Di samping menyelenggarakan pendidikan kejar paket A, lembaga pemasyarakatan Lowokwaru Malang, juga menyelenggarakan pendidikan kejar paket B dan pendidikan kejar paket C. Pendidikan ini diikuti oleh warga binaan yang tingkat pendidikannya untuk paket B setara dengan pendidikan formal SLTP (sekolah lanjutan tingkat pertama), dan untuk pendidikan kejar paket C setara dengan pendidikan formal SLTA (sekolah lanjutan tingkat atas).

Hasil observasi peneliti di lapangan, Berbagai bekal sebagaimana disebutkan di atas, pendidikan kejar paket $\mathrm{A}, \mathrm{B}$, dan $\mathrm{C}$, membentuk pribadi warga binaan yang lebih berkualitas yang berhubungan dengan solf skill dan hard skill warga binaan, sehingga memiliki bekal kehidupan yang lebih mantap dan berperilaku religius.
Agama atau kepercayaan merupakan salah satu norma/aturan yang sangat penting, mengatur kehidupan dan kepercayaan warga binaan sebagai pedoman hidup dalam hubungannya dengan Tuhan yang maha Esa, dan juga pedoman dalam berinteraksi untuk kepentingan dunia maupun akherat. Norma agama, menyangkut perbuatan yang boleh dilakukan maupun perbuatan yang tidak boleh dilakukan. Ukuran boleh dan tidak boleh dilakukan itulah yang ditanamkan dengan sungguh-sungguh sesuai dengan akidah agama dan kepercayaanya. Untuk itu, petugas lembaga pemasyarakatan bekerjasama dengan para Guru dan ahli agama, dan mubaliq.

Perilaku warga binaan adalah suatu kegiatan dan aktifitas organisme yang bersangkut-paut dengan aktifitas warga binaan yang dapat diamati maupun yang tidak dapat diamati oleh peneliti. Pada dasarnya warga binaan narkoba berperilaku karena mempunyai kebutuhan untuk mencapai suatu tujuan (goal), oleh karena itu, dengan adanya suatu tujuan maka muncul motivasi atau penggerak yang bertujuan untuk mencapai suatu tujuan (goal), sehingga warga binaan melakukan perilaku untuk mencapai tujuan. Tujuan itu diantaranya secara disiplin mengikuti program pemasyarakatan agar memperoleh remisi, cuti bersyarat, pelepasan bersyarat, dan sebagainya.

Di sisi lain, perilaku adalah respon warga binaan narkoba terhadap stimulasi, baik yang berasal dari petugas lembaga pemasyarakatan maupun dari luar para mubaliq. Oleh karena itu, setelah warga binaan narkoba masuk ke lembaga pemasyarakatan mengikuti program pemasyarakatan, merespon stumulasi yang diberikan oleh petugas lembaga pemasyrakatan.

Perilaku yang dapat ditunjukkan oleh warga binaan adalah perilaku ideal (ideal behavior), perilaku sekarang (curent behavior), dan perilaku yang diharapkan (expected/fesible behavior). Terhadap warga binaan patuh dan taat terhadap peraturan 
dan tata-tertib, dipercaya menjadi tamping, diikut sertakan diberbagai kegiatan di luar lembaga pemasyarakatan. Dengan perperilaku ideal mengharapkan berubah seperti falsafah yang dicitacitakan yaitu pemasyarakatan, diantaranya bersikap dan berperilaku religius.

Warga binaan berperilaku baik, artinya patuh dan taat pada aturan dan norma-norna yang berlaku karena ada rangsangan emosional yang bersumber pada rasa takut, cinta, atau ada harapanharapan, sehingga berpengaruh pada sikap, perilaku, dan kehidupan sehari-hari warga binaan di lembaga pemasyarakatan Lowokwaru Malang.

\section{Faktor Eksternal Warga Binaan Narkoba dalam Kehidupan Religius}

Faktor eksternal berasal dari luar diri warga binaan narkoba yang mempengaruhi pembentukan kehidupan religius. Segala sesuatu yang dipelajari dan dialami bersama secara sosial oleh para anggota masyarakat (Horton dan Hunt, 1993,3). Begitu pula warga binaan narkoba, dipengaruhi oleh,Faktor Budaya, Faktor suku, dan Faktor Petugas Lembaga pemasyarakatan.

Faktor-faktor eksternal warga binaan pengedar narkoba di lembaga pemasyarakatan Lowokwaru Malang. Dari hasil observasi peneliti dari lapangan, dipengaruhi oleh beberapa hal, diantaranya:

1. Warga binaan termasuk kelompok penjahat residivis atau bukan kelompok penjahat residivis.

2. Kualifikasi tindak pidana yang dilakukan termasuk penjahat kategori berat atau penjahat kategori ringan.

3. Macam-macam atau jenis-jenis kejahatan yang dilakukan.

4. Faktor usia, terdiri dari usia dewasa, usia muda atau remaja, dan usia lanjut.

5. Penetapan status penghuni, sudah menjadi warga binaan atau masih berstatus tahanan, serta lamanya menghuni lembaga pemasyarakatan.

6. Lamanya masa hukuman berdasarkan putusan pengadilan yang dijalani di lemabaga pemasyarakatan.

7. Warga binaan itu berprestasi atau dianggap cakap untuk memimpin, membantu sebagai tamping, pemuka, dan dilibatkan pada berbagai kegiatan baik di dalam maupun di luar lembaga pemasyarakatan.

Dalam melaksanakan visi dan misi, motto dalam mengemban tugas mulia, petugas Lembaga pemasyarakatan Lowokwaru Malang adalah:

1. Asah, artinya mempertajam kemampuan;

2. Among/momong/ngemong, terkandung nilai dan makna yang sangat mendasar, yaitu mendidik dengan model tidak memaksa:

3. Mandiri, dalam keadaan apapun dapat berdiri sendiri.

Motto Pelayanan petugas lembaga pemasyarakatan Lowokwaru Malang untuk/warga binaan adalah sebagai berikut:

a. Cepat, artinya petugas lembaga pemasyarakatan memberikan pelayanan secara prima (exellence service);

b. Sederhana, artinya peberian perlakuan terbaik dalam memenuhi kebutuhan dan harapan ke depan;

c. Puas, artinya warga binaan merasa puas.

Upaya untuk memberikan bekal kepada warga binaan narkoba, semua komponen yang ada, memberikan kontribusi sesuai dengan bidangnya masing-masing. Namun demikian, yang terlibat langsung dalam perlakuan terhadap warga binaan narkoba adalah seksi bimbingan kemasyarakatan yang terdiri dari seksi bimbingan pengetahuan umum, seksi bimbingan olah raga dan kesenian, seksi bimbingan kemasyarakatan sosial, dan seksi bimbingan rohani. 
Sikap Warga Binaan Narkoba dalam Kehidupan Religius

Warga binaan pengedar narkoba, terlibat pula sebagai pencuri, perampok, pemabuk, penjudi, koruptor, pelecehan seksual, pecandu, bandar, Di samping itu, memperoleh celaan, predikat (label) yang negatif, sampah masyarakat, penyakit sosial, korak (kotoran rakyat), preman, gali (gabungan orang liar), dan sebagainya.

Bahwa pada dasarnya, warga binaan narkoba memiliki latar belakang tindakan yang buruk. Kebiasaan itu diperoleh dan dibawa masuk ke dalam lembaga pemasyarakatan. Kebiasaan-kebiasaan buruk itu sebagai pendorong atau pemicu untuk melakukan berbagai kejahatan narkoba, bahkan kebiasaan buruk itu dibawa hingga proses hukum selesai dan masuk ke lembaga pemasyarakatan.

Warga binaan narkoba sebagian besar memiliki kepandaian dan intelegensi tinggi, lebih-lebih sebagai pengepul atau bandar yang mengatur jaringan peredarannya, harus mampu berfikir untuk menghindari kejaran aparat penegak hukum. Perilakunya pada dasarnya cenderung salah arah, pada akhirnya melakukan kejahatan, dengan kepribadian yang jahat sulit dibina dan diarahkan ke hal-hal yang baik, di lembaga pemasyarakatan Lowokwaru Malang ada yang dengan cara-caranya sendiri kedapatan melakukan komunikasi dengan jaringan pengedar narkoba, ada juga yang kedapatan menyimpan narkoba, kedapatan membawa HP (hand phone). Hal ini memberikan petunjuk bahwa warga binaan narkoba memiliki kepandaian dan intelegensi yang tinggi, mengelabui petugas, bahkan upaya petugas lembaga pemasyarakatan menegakkan disiplin tidak menjadikan mereka tobat dan jera untuk melakukan kejahatan narkoba lagi dengan cara-cara yang canggih (sovesticated).

Pada perspektif ini, untuk membangun kebiasaan yang baik dan religius dalam kehidupan sehari-hari dilakukan dengan menanamkan hu- bungan persaudaraan antara sesama warga binaan narkoba tanpa dipengaruhi oleh suku, ras, agama, dan golongan, misalnya saling memberi ucapan selamat ketika peringatan hari raya Agama Islam, ulang tahun, dan sebagainya. Di samping itu, di lembaga pemasyarakatan Lowokwaru Malang juga ditanamkan rasa saling menyayangi terhadap sesama.

Berbagai kegiatan keagamaan di Masjid At"Taubah dijadikan sarana pembinaan dalam upaya untuk menumbuhkan kebiasaan agar berperilaku religius, misalnya sholat wajib berjamaah, sholat jum" at berjamaah, belajar baca tulis $\mathrm{Al}$ Qur'an, memberi ceramah agama pada sesama warga binaan narkoba, dan sebagainya.

Ekspresi warga binaan narkoba memberikan gambaran konkrit tentang terjadinya perubahan ke arah positif, kebiasaan-kebiasaan tersebut menjadi modal utama dalam kehidupan yang lebih baik. Hal ini didasarkan pada keyakinan atas fitrah manusia sesungguhnya adalah baik, namun, pada warga binaan narkoba mengalami pergeseran menjadi jahat. Sifat jahat disebabkan oleh beberapa faktor, yaitu faktor internal dan faktor eksternal.

Faktor Internal; dari kedua orang tuanya tidak efektif dalam membentuk pribadi, lingkungan keluarganya tidak harmonis, kemiskinan, rendahnya tingkat pendidikan, rendahnya pemahaman dan penghayatan terhadap agama dan kepercayaan yang dianut.

Pada dasarnya warga binaan narkoba sebelum masuk ke lembaga pemasyarakatan adalah berperilaku jahat/penjahat. Akibat dari perilaku jahat yang dilakukan membawa ke dalam proses hukum dan diputus oleh hakim sebagai terpidana dan akhirnya menjadi warga binaan. Latar belakang internal perilaku dominan warga binaan lembaga pemasyarakatan Lowokwaru Malang, pada dasarnya jahat, didasari oleh berbagai latar belakang nilai-nilai kehidupan sosial dari asalnya, nilainilai kehidupan religius yang dimiliki dan diyakini, dan dasar keahlian serta ketrampilan yang belum terorganisir secara baik. 


\section{Jurnal Cakrawala Hukum \\ Vol.7, No.1 Juli 2016: 66-81}

\section{Penutup}

Bahwa warga binaan narkoba sejak awal tertangkap petugas penegak hukum sedang, kedapatan, patut diduga melakukan kejahatan narkoba, berperilaku jahat, melawan hukum, dan melakukan perbuatan bertentangan dengan norma-norma yang berlaku. Dalam kaitan ini, lembaga pemasyarakatan sebagai institusi urutan terakhir dalam proses penegakan hukum dan perlakuan terhadap warga binaan pengedar narkoba, bertugas menggali, mengubah pikiran jahat menjadi perilaku religius dalam kehidupannya. Di dalam lembaga pemasyarakatan, perilaku religius terakumulasi pada penghargaa terhadap warga binaan pengedar narkoba ada yang menjadi tamping, hal ini merupakan bukti nyata perubahan yang signifikan terhadap sikap, perilaku, mental spiritual, sehingga pantas mejadi teladan bagi yang lain.

Perspektif kehidupan sosial warga binaan narkoba di lembaga pemasyarakatan merupakan proses evolusi, secara ideal bersifat demokratis, moral dan progresif. Hal tersebut terjadi pada masyarakat warga binaan narkoba lembaga pemasyarakatan Lowokwaru Malang, sesungguhnya selalu berperilaku konformis untuk menuju kehidupan religius, ketika dibangun hubungan yang harmonis, apabila dijalin dengan norma-norma dan kaidah-kaidah yang mengatur kehidupannya, untuk kepentingan komunikasi, interaksi, dan partisipasi. Dimensi interaksionis ini, komunitas yang berhubungan dengan masyarakat lembaga pemasyarakatan, mengikuti perkembangan sejalan dengan perkembangan kehidupan sosial pada umumnya.

\section{DAFTAR PUSTAKA}

\section{Buku}

Abdullah, Taufik dan A.C. Van Der Leeden, 1986, Durkheim dan Pengantar Sosiologi Moralitas, Jakarta, Yayasan Obor Indonesia.

Achmad, S. Soemadipradja dan Romli Atmasasmita, 1979, Sistem Pemasyarakatan di Indonesia, Jakarta, Bina Cipta.
Ahmadi, Abu 1991, Sosiologi Pendidikan, Jakarta, Rineka Cipta.

Ali, Achmad, 1998, MenjelajahiKajian Empiris Terhadap Hukum, Jakarta, Yarsif Watampone.

Anderson, Stephen K., 1991, Sosiologi Makro Sebuah Pendekatan TerhadapRealitas Sosial, (Jakarta, Rajawali Press).

Blau, Peter, 1987, "Microprocess and Macrostructure”, dalam Karen S. Cook(ed). Social exchange theory, Beverly Hill, Calif, Sage.

Berger, Peter L., 1996, Piramida Kurban Manusia, Etika Politik dan Perubahan Sosial, (Jakarta, LP3ES).

Berger, Peter L. dan Lukman Thomas, 1990, Tafsir Sosial Atas Kenyataan, (Jakarta, LP3ES).

Blumer, Herbert, 1953, "Social Movement Principles of Sociology, Alfret M. Lee edt, New York, Barnes \& Noble Inc.

- - - - , Herbert, 1969, Symbolik Interactionism Perspective and Method, Engelwood, Cliffs. N. Y. Prentice Hall, Inc.

Bonger, W.A., 1962, Pengantar Tentang Kriminologi, Jakarta, PT. Pembangunan.

Bungin, Burhan, 2003, Analisis Data Dalam Penelitian Kualitatif Pemahaman Filosofis dan Metodologis Ke arah Penyusunan Model Aplikasi, (Jakarta,PT. Raja Grafindo Perkasa).

Caney, Simon, 2002, "Equal Treatment, Exceptions and Cultural Diversity" dalam Kelly (ed.), Multiculturalism Reconsi-dered, (Cambridge U.K., Polity Press).

Carney, Louis P, 1974, Introduction to Correctional Science, Mc. Graw-Hill, New York.

Glazer, Nathan, 1997, We Are All Multiculturalists Now, Cam-bridge, Mass, Harvard University Press.

Griffin, Emory, A., 2003, A First Look at Communication Theory, $5^{\text {th }}$ New York, Mc. Graw Hill.

Hamzah, Andi dan Siti Rahayu, 1983, Suatu Tinjauan Ringkas Sistem Pemidanaan di Indonesia, Jakarta, Akademi Presindo.

Hefner, Robert W (ed), 2007, Politik Multikulturalisme Menggugat Realitas Kebangsaan, Yogyakarta, Kanisius. 


\section{Pembinaan Narapidana Narkotika dan Obat Obatan Berbahaya (Narkoba) dalam Perspektif Kehidupan Religiusitas}

Teguh Suratman

Himawan, Charles, 2003, Hukum Sebagai Panglima, Jakarta, Kompas.

Kartono, Kartini, 2009, Patologi Sosial, Jakarta, Rajawali Pers.

Martin, James F., and Franklin, Clyde W.,1973, Minority Group Relations. Charles E. Merril Pub. Co, A Bell \& Howel Co, Columbus, Ohio.

Masinambow, E.K.M. 1997, Pengantar, Koentjaraningrat dan Antropologi di Indonesia, dalam buku Koentjaraningrat dan Antropologi di Indonesia, Jakarta, AAI bekerja sama dengan Yayasan Obor.

Mead, George H., 1967, Mind, Self and Society, Chicago, The University of Chicago Press.

Moeljatno, 1975, Fungsi dan Tujuan Hukum Pidana Indonesia dan Rancangan Undang Undang Tentang Asas Asas dan Dasar Dasar Pokok Tata Hukum Indonesia, Jakarta, Bina Aksara.

Parekh, Bikhu, 2008, Rethinking Multiculturalism Keberagaman Budaya dan Teori Politik, Yogyakarta, Kanisius.

Parsons, Talcott, 1961, The Social System, New York, The Free Press.

Poernomo, Bambang, 1986, Pelaksanaan Pidana Penjara Dengan Sistem Pemasyarakatan, Liberty, Yogyakarta.

Satjipto, Rahardjo, 2007, Membedah Hukum Progresif, Jakarta, Kompas, Penerbit Buku Kompas.

Raho, Bernhard, 2007, Teori Sosiologi Modern (Jakarta, Prestasi Pustaka Publisher) Rex. John. 1985, The Conflict of Multiculturalism Society Ocational Paper in Ethnic Relations No. 3 Centre for Research in Ethnic Relation (CRER).

Ritzer, George \& Goodman, Douglas, 2004, Teori Sosiologi Modern, Jakarta, Prenada Media Group.

Sahetapy, J. E., 1982, Suatu Studi Khusus Mengenai Ancaman Pidana Mati Terhadap pembunuhan Berencana, Jakarta, Rajawali.
Salim, Agus, 2006, Stratifikasi Etnik Kajian Mikro Sosiologi Interaksi Etnis Jawadan China, Yogyakarta, Tiga Kencana.

Santosa, Listiono, dkk. 2007, Epistemologi Kini,Yogyakarta, Ar'Ruzz Media.

Simanjuntak, B, 1975, Psikologi Perkembangan, Bandung, Tarsito.

Sugiono, 2005, Memahami Penelitian Kualitatif, (Bandung, Alfabeta).

Sugiono, 2011, Metode Penelitian Kuantitatif Kualitatif dan RED, (Bandung, Alfabeta).

Sukidin Basrowi, 2002, Metode Kualitatif Perspektif Mikro, (Surabaya, Insan Cendekia).

Susan, Novri, 2009, Sosiologi Konflik dan Isu-isu Konflik Kontemporer (Jakarta, Kencana).

Suparlan, Parsudi, 2002, "Mепијu Masyarakat Indonesia yang Multikultural", Materi pada Simposium Internasional Jurnal Antropologi Indonesia ke-3 di Denpasar Bali, 16-21 Juli 2002.

Strauss, A. L. Dan J. Corbin, 1990, Basic Qualitative Research, Grounded Theory Procedures and Techniques, (London, Sage Publications).

Strauss, Anshem L, 1989, Qualitative Analysis for Social Scientist, (Cambridge, University Press).

Susanto, Astrid, 2006, Pengantar Sosiologi dan Perubahan Sosial, Bandung, Bina Cipta.

Warsi Bachtiar, 2006, Sosiologi Klasik Dari Comte Hingga Parsons, Bandung, Remaja Rosda Karya.

Water, Malcom, 1994, Modern Sociological Theory, London, Thousand Oaks.

Wieviorka, Michel. 1998, "Is Multiculturalism the Solution", di dalam Ethnic and RacialStudies, Routledge. 